\title{
Role of Levoatrial Cardinal Vein Plugging in Single Ventricle Palliation
}

\author{
Vivek Kumar ${ }^{1 *}$, Gaurav Kumar ${ }^{2}$, Nikhil Tiwari ${ }^{2}$ and Sajan Joshi ${ }^{3}$ \\ ${ }^{1}$ Pediatric Cardiologist, Army Hospital Research and Referral, India \\ ${ }^{2}$ Pediatric Cardiac Surgeon, Army Hospital Research and Referral, India \\ ${ }^{3}$ Pediatric Anaesthetist, Army Hospital Research and Referral, India
}

Submission: May 25, 2018; Published: August 09, 2018

*Corresponding author: Vivek Kumar, Classified Specialist Pediatrics and Pedediatric Cardiologist, Army Hospital Research and Referral, Dhaulakuan, Delhi cantt-110010, India, Tel: 7042743322; Email: vk3532@gmail.com

Keywords: Levoatrial cardinal vein; Bidirectional glenn

Abbreviation: LACV: Levoatrial Cardinal Vein; UAVSD: Unbalanced Atrioventricular Septal Defect; AVPII: Amplatzer Vascular Plug II

\section{Introduction}

We describe a serendipitous finding of Levoatrial Cardinal Vein (LACV) in a post bidirectional glenn patient for Unbalanced Atrioventricular Septal Defect (UAVSD) severe pulmonary stenosis. The culprit vein was causing severe desaturation and symptoms. The symptomatology and saturation improved after its plugging and also the patient could be taken up for final stage palliation.

\section{Case Report}

A four-and-a-half-year-old female toddler reported to our hospital with the history of undergone bidirectional glenn shunt at one year of age outside for UAVSD. Child had not undergone cardiac catheterization before glenn surgery. She was severely symptomatic for the past one and half years with class III symptoms and worsening cyanosis. On examination she weighed $15 \mathrm{~kg}$, her vital parameters were within normal limits and she had severe cyanosis (oxygen saturation 65\%) and grade III clubbing. Cardiovascular examination showed single S1 and S2 with no murmur. Patient was planned for diagnostic catheterization to find out the cause for severe desaturation and to assess the suitability for final stage of palliation. Investigation showed hemoglobin of $18 \mathrm{gm} \%$ with $60 \%$ hematocrit and normal biochemical parameters. Patient cardiac catheterization was done after heparinisation at $100 \mathrm{U} / \mathrm{kg}$. It showed functional glenn shunt with adequate branch pulmonary arteries and a large levoatrial cardinal vein $(10.4 \mathrm{~mm})$ connecting left brachiocephalic vein to left atrium (Figure 1), (Video 1). Atrial pressures were $13 \mathrm{mmHg}$, while mean pulmonary artery pressure was $16-17 \mathrm{mmHg}$. It was decided to plug the vein presently with Amplatzer Vascular Plug II (AVPII). Left subclavian vein access was taken with a $5 \mathrm{Fr}$ short sheath and a super stiff amplatz wire was parked in the Left atrium. Now a 8Fr long cook sheath was exchanged over the wire and a $14 \mathrm{~mm}$ AVP II was deployed at the junction of brachiocephalic vein with LACV. Repeat contrast injection showed device in place with no flow across the plug (Figure 2). Saturation on table improved to $80 \%$, repeat mean PA pressures were $16-17 \mathrm{mmHg}$. Patient was observed for a day and discharged on medical management (Aspirin and iron) as the high PA pressure precluded from performing fontan completion. Patient reported after 6 months for review, she had class II symptoms and saturated 76-80\%. Repeat cardiac cath data to our surprise, showed reduced mean PA pressure of $13 \mathrm{mmHg}$ and atrial pressures as $11 \mathrm{~mm} \mathrm{Hg}$. She underwent successful extra cardiac fontan completion. On follow-up at one month she had no complaints and doing well.

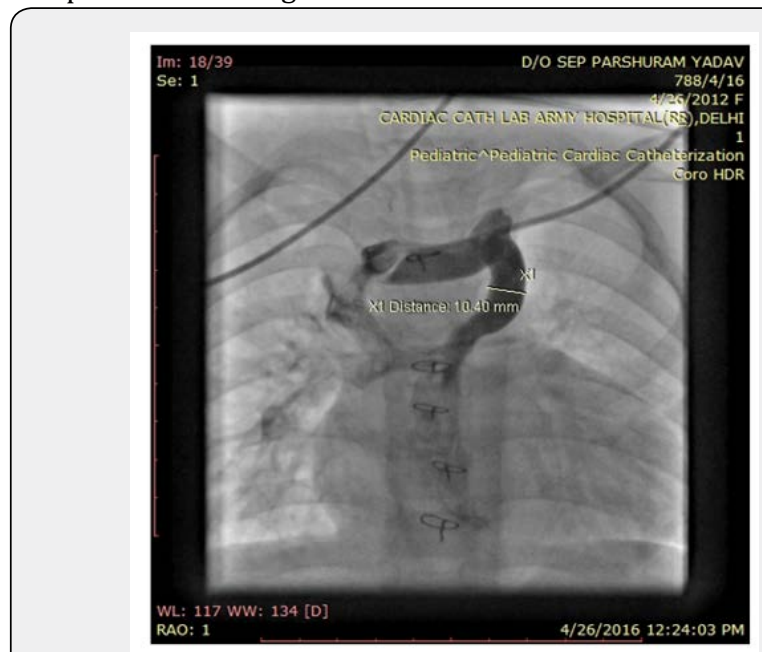

Figure 1: Angio showing levoatrial cardinal vein connecting brachiocephalic to left atrium. 


\section{Journal of Cardiology \& Cardiovascular Therapy}

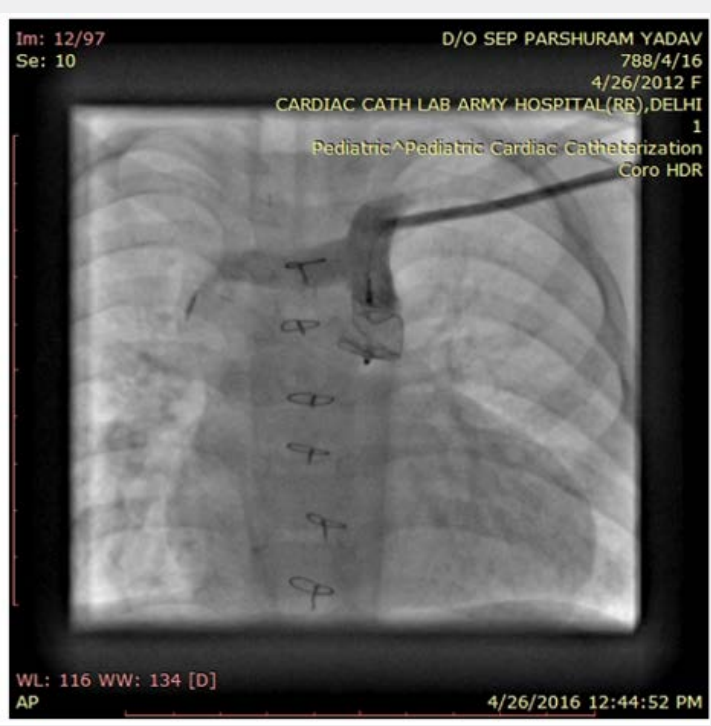

Figure 2: Angio showing final deployment of the device.
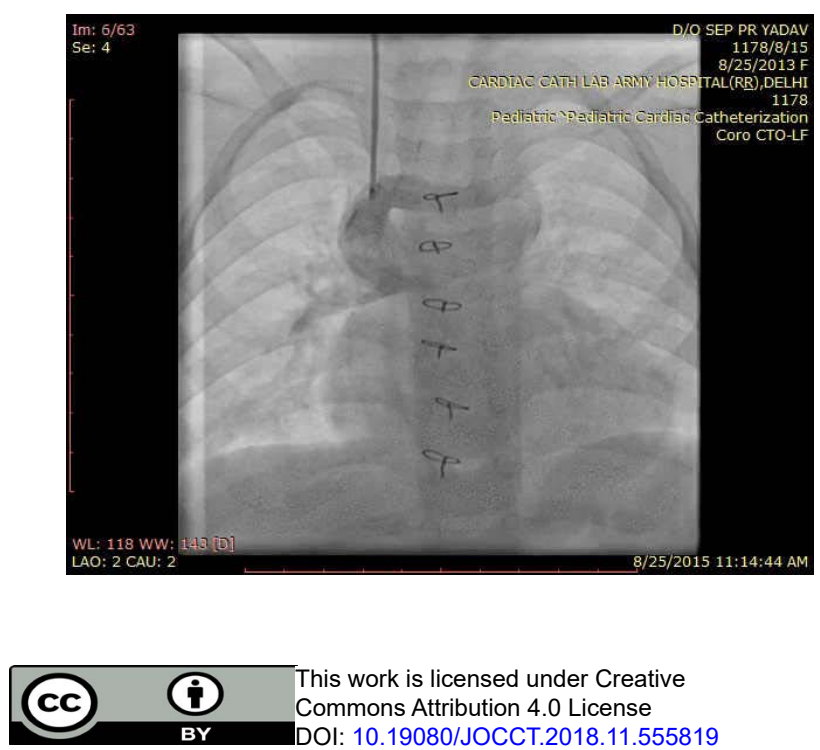

\section{Discussion}

Levoatrial cardinal vein is a rare systemic vein cardiac anomaly which connects left atrium to systemic veins either brachiocephalic or vena cava. It is generally seen in left sided obstructing lesions like aortic atresia, mitral atresia or cortriatriatum [1]. This vein serves to decompress left atrium to systemic veins [2,3]. Its presence in our patient is a rare and an interesting finding. Hemodynamically it created a right to left shunt causing severe cyanosis. It was missed at glenn stage as no cardiac catheterization was done. What caused the raised pulmonary artery pressures? which got settled after the procedure in acceptable range, is difficult to postulate. However, the procedure alleviated the symptoms of the patient following saturation improvement and also the patient became fit for fontan completion.

\section{References}

1. Sadler TW (1995) Langman's medical embryology. Lippincott Williams \& Wilkins, Baltimore, Maryland, USA, pp. 219-224.

2. McIntosh CA (1926) Cor biatriatum triloculare. Am Heart J 1(6): 735744.

3. Edwards JE, Du-Shane JW (1950) Thoracic venous anomalies. I. Vascular connection of the left atrium and the left in nominate vein (levoatriocardinal vein) associated with mitral atresia and premature closure of the foramen ovale. II. Pulmonary veins draining wholly into the ductus arteriosus. Arch Pathol 49: 517-537.

Your next submission with Juniper Publishers will reach you the below assets

- Quality Editorial service

- Swift Peer Review

- Reprints availability

- E-prints Service

- Manuscript Podcast for convenient understanding

- Global attainment for your research

- Manuscript accessibility in different formats

( Pdf, E-pub, Full Text, Audio)

- Unceasing customer service

Track the below URL for one-step submission https://juniperpublishers.com/online-submission.php 